\title{
ESTIMATION AND MODELING OF THE INFLUENCE OF WEATHER AND CLIMATIC CONDITIONS ON THE YIELD OF WINTER WHEAT
}

\author{
A. Mohylnytska, Candidate of Physical and Mathematical Sciences \\ ORCID ID: 0000-0002-4349-3576 \\ A. Panfilova, Candidate of Agricultural Sciences, Associate Professor \\ ORCID ID: 0000-0003-0006-4090 \\ Mykolayiv National Agrarian University
}

The article considers the agro-climatic conditions of winter wheat cultivation under different feed options in Ukraine. It gives a detailed analysis of the air temperature change, precipitation, relative humidity and their mixed effect on winter wheat productivity for each phase of field crop development, as well as changes in climate fertility and crop efficiency in the modern climate period (2012-2016). The main sample characteristics of the interaction results of wheat varieties are found and the multifactor regression of yield dependence on hydrometeorological factors is formed.

\section{Keywords: yield, agroclimatic conditions; winter wheat; regression; correlation.}

The reality of nowadays is to find priority areas and support those industries that will give Ukraine the opportunity to engage its own niche in the world. One of these areas is the agricultural sector. Even during the general crisis, agricultural products will be in demand. The Food and Agriculture Organization of the United Nations (FAO) predicts that global food production should grow to $70 \%$ till 2050 to meet the needs of the nine billion population.

There is a need to study both the benefits and risks for the agricultural sector. Latest in general include noticeable climate changes, under the influence of which, we see that food security in the long term depends on how it is possible to modernize the traditional model of agricultural production, due to possible weather and climate shifts [10, 23].

Climate changes are manifested in an increase in the average annual temperature on the surface of the planet, an increase in the level of the oceans, an increase in the number of natural disasters and cataclysms (desertification, landslides, hurricanes, etc.). According to the Institute of irrigated agriculture of the National Academy of Sciences [3, 4] over the past 35 years in the dry Steppe subzone, there is a steady trend of increasing the average annual temperature from $9.3(1973-1980)$ to $11.3^{\circ} \mathrm{C}$ (2006-2010), that is, by $2^{\circ} \mathrm{C}$. At the same time, there is a tendency to increase precipitation of a storm nature and increase the wind regime, which leads to water erosion and soil deflation.

Temperature increases occurs too fast then compared global rates [21], which are caused by human-made emissions. The IV Report of the
Intergovernmental Panel on Climate Change (IRCC) shows the unprecedented rate of increase greenhouse gases in the atmosphere over the past 150 years. According to the latest data, the concentration of these harmful gases in the Earth's atmosphere increased by $31 \%$ (carbon dioxide) and $149 \%$ (methane) compared to their amount at the beginning of the Industrial Revolution. About half of all greenhouse gases produced in the course of human economic activity remain in the atmosphere [24].

Climate changes pose a real danger to Ukraine, since due to insufficient moisture reserves in the soil, it is very difficult to form a crop of agricultural crops. In addition, strong winds are more often observed, which interfere with the timely application of plant protection products and lead to wind erosion of soils. Together with warming, there is a probability of a 1.52-times increasing the number of insect pests, for whom these conditions are a favorable factor for reproduction and spreading [17].

Based on climate change simulations conducted by Cambridge Group climate scientists from all over the world, under the auspices of the UN FAO, further air temperature will increase in the range from 2 up to $6^{\circ} \mathrm{C}$ is predicted up to $2100 \mathrm{yr}$ period. Such an increase in temperature and $\mathrm{CO} 2$ concentration in the air will have a direct impact on the Earth's biosphere, including the productivity of the agro-industrial complex, yield and quality of agricultural products. Negative climate changes in the nearest future includes rise up in air temperature, rise up in the effect of droughts, shortage in snow cover, an interruption of precipitation even flow, which in combination

(C) Mohylnytska A., Panfilova A., 2020 
leads to the activation of erosion processes and soil degradation [4].

Question of the dependence of crop yields on climatic factors was considered by leading scientists $[9 ; 1 ; 22]$. Generally scientists note, that while recent years in Ukraine, the work had been done to evaluate the response of grain crops on climate changes and growing conditions. For better information support of agricultural production, it is advisable to provide forecasting of the productivity of individual crops on local, regional and state levels [7, 8]. One of the problems of plant adaptation to local agroclimatic conditions is the establishment of an optimal level of heat and moisture.

Under such conditions, according to some estimates, the global wheat grain production may soon decrease on $6 \%$ with temperature increase for each Celsius degree [15].

For gathering high yields, favorable weather conditions are necessary during plant vegetation, but the latter depend on natural factors that cannot be managed or corrected [14]. Winter wheat in the process of growth and development goes through two periods, which depend on weather and climatic conditions. During the first period of plant growth, vegetative organs are formed mainly, which are responsible for the main functions in the body such as supply, respiration, water exchange, etc. The second period goes with organization of generative organs (ear, spikelets, flowers and grains).

The most important for winter crops is the first period passing in autumn, during which plants actively grow, go through the initial stages of organogenesis in the growth cone, where the main productive organs are in their infancy, and sugars accumulate as protective compounds before wintering [13].

Despite the large volume of theoretical and experimental studies, the influence of weather and climatic conditions on the yield of winter wheat in the Southern Steppe of Ukraine is insufficiently studied and it requires constant research. Therefore, there is a need to build a model of changes in exogenous indicators (the amount of precipitation during the vegetation of the crop, changes in the temperature regime of air and its humidity), which cause changes in endogenous ones (the yield of winter wheat grain).

Tasks and methods of research. Experimental studies were conducted during 2011-2016yrs in the experimental field of the Mykolaiv NAU. The object of research was winter wheat. The technology of growing crops, except of the studied factors, was generally accepted to the existing zonal recommendations for the Southern Steppe of Ukraine.

The experiment scheme included the following options:

Factor A - variety: 1. Kolchuga; 2.Zamozhnist.

Factor B - nutrition: 1. control (without fertilizers); 2. N30P30 - for pre-sowing cultivation background; 3. background + Urea K1 (1 1/ha); 4. background + Urea K2 (1 1/ha); 5. Background + Escort-Bio (0.5 1/ha); 6. Background + Urea K1 + urea K2 (0.5 1/ha each); 7. Background + Organic D2 (1 l/ha). The rate for the working solution was 200 1/ha. The replenishment of crops with growthregulating drugs was done both times at the beginning of spring vegetation reduction and at the beginning of going winter wheat into tubing stage. The yield was measured with the method of total moving from each reported field part (combine-harvester "Sampo $130 ")$.

The variance and correlation-regression analyses were performed $[5,12]$, to estimate the influence of meteorological factors on the yield.

Research results. Our research shows that yield of winter wheat grain is changes under the influence of varietal characteristics, the background of nutrition, weather and climatic conditions of the growing year, the supply of plants with moisture during the vegetation.

Weather and climatic conditions during the growth and development periods of winter wheat plants for 2012-2016yrs are shown on Fig. 1-3..

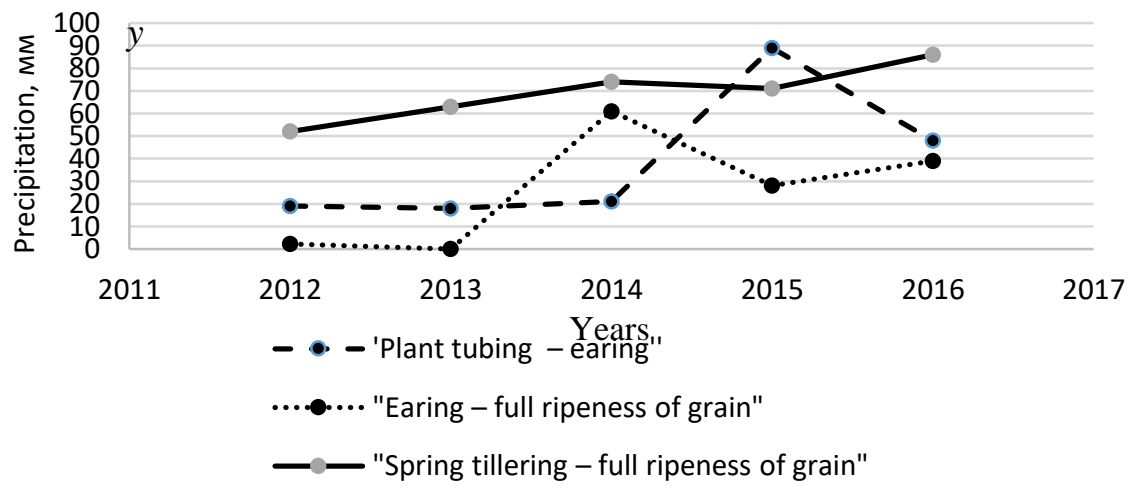

Figure 1. The amount of precipitation occurred during the interphase periods of growth and development of winter wheat plants, $\mathrm{mm}$ 
According to the analyses of meteorological indicators, it was pointed that maximum amount of precipitation (Fig.1), specifically $83.0 \mathrm{~mm}$ were received in 2016 years during the interphase period of earing-full grain ripening. The lowest amount of precipitation was in 2013year. So, in the interphase period "plant tubing - earing", there were no precipitation at all. During the period "spring tillering - full ripeness of grain", $81 \mathrm{~mm}$ of precipitation appeared. It should be noted that in 2012 year, the lowest amount of precipitation, which is $73 \mathrm{~mm}$, appeared during the interphase period "spring tillering - full ripeness of grain", and in 2015 year the highest amount of precipitation, which is $188 \mathrm{~mm}$.

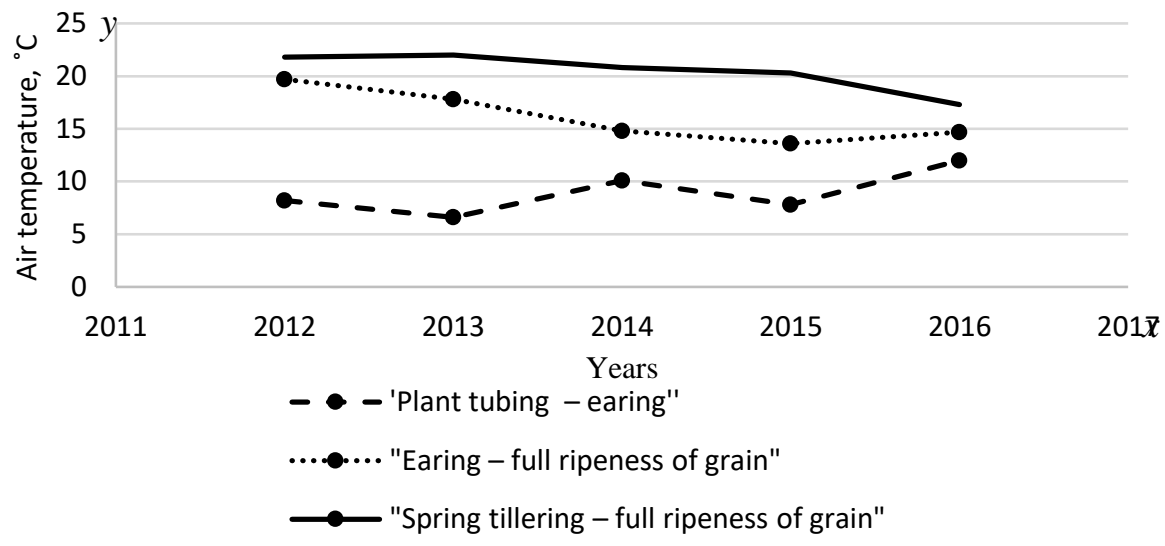

Figure 2. Air temperature, $\mathrm{C}$

In general, temperature regime (Fig.2) had similar patterns, but it raised up in 2012yr and 2013yr during the interphase period from earing to full ripeness of winter wheat grain. The average air temperature in these years and interphase periods was +21.8 and 22.0 $0 \mathrm{C}$, respectively, what topped up the indicators of studied 2014-2016yrs on $4.6-20.6 \%$ and $5.5-21.4 \%$.
The relative air humidity had been changed during the studied years also, for the interphase periods of growth and development of winter wheat (Fig. 3). So, in 2012yr and 2016yr, it was the highest, respectively, in the interphase period "spring tillering - winter wheat plants tubing" and "earing - full ripeness of grain" $-74 \%$.

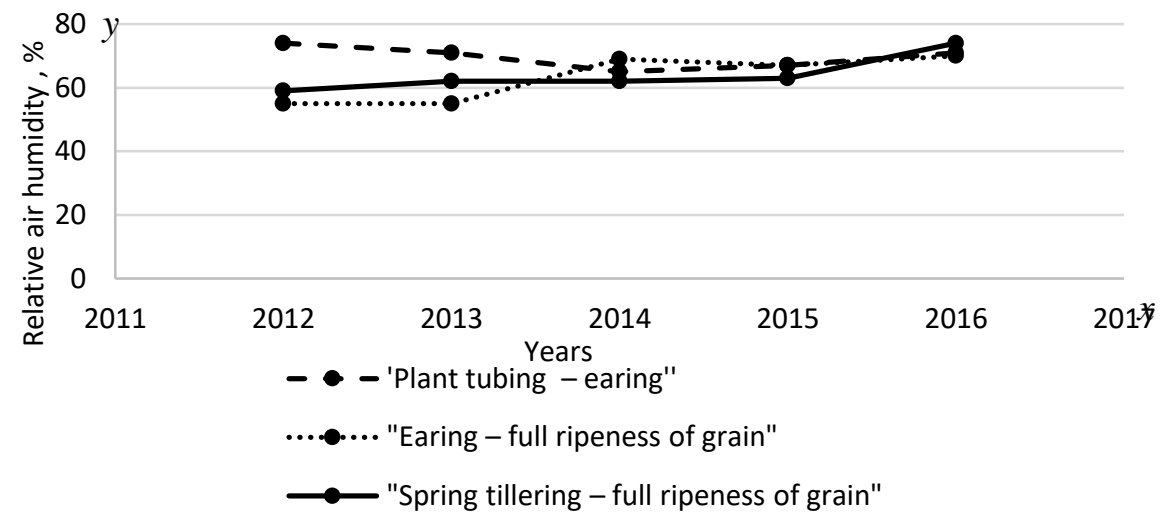

Figure 3. Relative air humidity, \%

Weather and climatic conditions of the years and factors of research (variety, way of nutrition) significantly affected on the yield of winter wheat grain (Table 1).

The lowest yield of winter wheat grain was formed in $2012 \mathrm{yr}$ as 1.71 up to $3.04 \mathrm{t} /$ ha by the Kolchuga variety and it was 1.86 up to $3.76 \mathrm{t} / \mathrm{ha}$ by the Zamozhnist variety, depending on the way of nutrition. Favorable weather conditions in $2015 \mathrm{yr}$ and 2016yr during the vegetation of plants ensured the highest yield of winter wheat grain, regardless of the factors studied. In average, for both varieties and way of nutritions, $5.53 \mathrm{t} / \mathrm{ha}$ of grain was formed in $2015 \mathrm{yr}$, and it was $5.59 \mathrm{t} / \mathrm{ha}$ in 2016yr, what exceeded their level in 2012yr, which became the least favorable, by 2.63 up to $2.69 \mathrm{t} / \mathrm{ha}$ or 90.7 up to $92.8 \%$.

Over the research years, the positive effect was shown with main moderate dose application of mineral fertilizers and foliar feeding procedures during vegetation of winter wheat varieties. So, over the research years, 3.44-3.58 t/ha of winter wheat 
grain were obtained with the background of N $30 \mathrm{P}$ 30 application, depending on the variety, which exceeded the control starting from 0.53 up to 0.55 t/ha and from 17.4 up to $19.0 \%$. More significant grain growth was formed with the options of crops fertilizing due to their background with Organic D2 and Escort-Bio preparations. Using of mentioned before preparations increased the yield of winter wheat Kolchuga variety staring from 1.53 up to 1.59 t/ha or from 52.9 up to $55.02 \%$; Zamozhnist variety from 1.91 up to 1.94 t/ha or from 62.6 up to $63.6 \%$, respectively.

Table 1

Winter wheat yield depending on varietal characteristics and optimization of nutrition, $t$ / ha

\begin{tabular}{|c|c|c|c|c|c|c|}
\hline \multirow{2}{*}{$\begin{array}{c}\text { Variety } \\
\text { (factor A) }\end{array}$} & \multirow{2}{*}{$\begin{array}{l}\text { Variant of nutrition } \\
\text { (factor B) }\end{array}$} & \multicolumn{5}{|c|}{ Years } \\
\hline & & 2012 & 2013 & 2014 & 2015 & 2016 \\
\hline \multirow{7}{*}{ 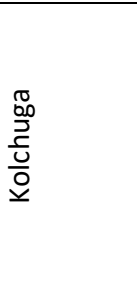 } & Control & 1,71 & 1,85 & 2,71 & 4,02 & 4,15 \\
\hline & $\mathrm{N}_{30} \mathrm{P}_{30}$ (background) & 2,23 & 2,36 & 3,13 & 4,71 & 4,78 \\
\hline & Background +Urea K1 & 2,73 & 3,29 & 3,78 & 5,64 & 5,69 \\
\hline & Background + Urea K2 & 2,79 & 3,37 & 3,90 & 5,78 & 5,82 \\
\hline & Background + Escort-Bio & 3,04 & 3,49 & 3,97 & 5,93 & 5,99 \\
\hline & Background+ Urea K1 + Urea K2 & 2,91 & 3,44 & 3,94 & 5,82 & 5,77 \\
\hline & Background + Organic D2 & 2,97 & 3,42 & 3,98 & 5,74 & 5,98 \\
\hline \multirow{7}{*}{ 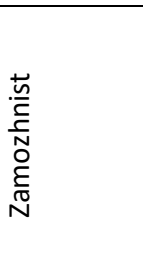 } & Control & 1,86 & 1,99 & 2,90 & 4,20 & 4,28 \\
\hline & $\mathrm{N}_{30} \mathrm{P}_{30}$ (background) & 2,35 & 2,47 & 3,35 & 4,86 & 4,89 \\
\hline & Background +Urea K1 & 3,32 & 3,74 & 4,21 & 5,96 & 5,99 \\
\hline & Background + Urea K2 & 3,54 & 3,95 & 4,42 & 6,09 & 6,13 \\
\hline & Background + Escort-Bio & 3,76 & 4,14 & 4,55 & 6,24 & 6,28 \\
\hline & Background+ Urea K1 + Urea K2 & 3,71 & 4,11 & 4,46 & 6,21 & 6,25 \\
\hline & Background + Organic D2 & 3,72 & 4,20 & 4,39 & 6,20 & 6,31 \\
\hline
\end{tabular}

Essential things to ensure the manufacturing stability in the Agro-Industrial Complex are crop yield forecasts, which can provide a significant improvement in foreign trade activities; reducement of imports cost and export revenues increasement of agricultural products; capacity and structure optimization of reserve funds and reserves [11, 26, 27].

An outstanding feature of the grain production process in Ukraine is a sharp increase of yield variance over last years (Fig. 4 and 5). This trend can be explained by the influence of meteorological factors that goes through the similar changes $[2,16$, $18,20]$.

Using data of the winter wheat yield depending on the optimization of nutrition and varietal characteristics, we will test the hypothesis at the level of significance $\alpha=0,05$ : based on that both varieties of winter wheat have the same yield.

Let's create a single-factor analysis of variance using the Excel add-in "Data Analysis" (Fig. 4 and 5).

Analyzing the data in Figures 4 and 5, we can say that the Zamozhnist variety is more better, since with some options of nutrition, its yield is higher and more stable. So for the Kolchuga Variety, the selective coefficient of yield of variation $\left(v_{i}^{*}=\frac{S_{i}}{y_{i}^{*}}\right.$, $S_{i} \quad-\quad$ variance) acquires the values: $41,4 \% \leq v_{i}^{*} \leq 46,5 \%$, and for Zamozhnist $28,3 \% \leq v_{i}^{*} \leq 44,3 \%$. The same time, the highest average yield $\overline{y^{*}}=4,994 ; v^{*}=28,3 \%$ - is for the Zamozhnist winter wheat variety, while for Kolchuga this indicator is: $\overline{y^{*}}=4,484 ; v^{*}=42,9 \%$.

Using the data in the Table of variance analysis (Fig. 4 and 5), let's calculate how significant the differences in yields is. Marked $F<F k p$, and $p>a$, it can be pointed that the hypothesis about the influence of weather and climatic conditions on the yield of these winter wheat varieties is not contradicting real data of research.

To plan the job in the agricultural sector, it is necessary to have such evaluate performance of indicators in the annual outlook. The most successful forecasts are effected when an adequate mathematical model of the object is created, which shows timely and consistent information about the expected levels of crop production [6, 25]. Quite serious realistic successes in this direction did allow us to consolidate confidence that mathematical models can become an effective way of large set integrating of theoretical ideas about the life of agroecosystems for solving practical problems [2, $28,29,30]$.

To identify the influence of climatic factors on the yield of winter wheat, an effective tool is regression model analysis based on the collected experimental observations [19]. The most common technical method in correlation studies is the least squares method (OLS). 


\begin{tabular}{|c|c|c|c|c|c|c|c|}
\hline$\Delta$ & A & B & C & D & $\mathrm{E}$ & $\mathrm{F}$ & G \\
\hline 1 & \multicolumn{7}{|c|}{ Single-factor dispersion yield analysis (Kolchuga variety) } \\
\hline 2 & & & & & & & \\
\hline 3 & RESULTS & & & & & & \\
\hline 4 & Groups & Score & Sum & Mean & Dispersion & & \\
\hline 5 & Control & 5 & 14,44 & 2,888 & 1,34272 & & \\
\hline 6 & $\mathrm{~N}_{30} \mathrm{P}_{30}$ (background) & 5 & 17,21 & 3,442 & 1,53377 & & \\
\hline 7 & Background + Urea K1 & 5 & 21,13 & 4,226 & 1,86393 & & \\
\hline 8 & Background + Urea K2 & 5 & 21,66 & 4,332 & 1,95017 & & \\
\hline 9 & Background + Escort-bio & 5 & 22,42 & 4,484 & 1,92408 & & \\
\hline 10 & $\begin{array}{l}\text { Background + Urea K1 + } \\
\text { Urea K2 }\end{array}$ & 5 & 21,88 & 4,376 & 1,81093 & & \\
\hline 11 & Background + Organic D2 & 5 & 22,09 & 4,418 & 1,86802 & & \\
\hline 12 & & & & & & & \\
\hline 13 & & & & & & & \\
\hline 14 & Dispersion analysis & & & & & & \\
\hline 15 & Source of variation & $S S$ & $d f$ & $M S$ & $F$ & P-Value & F tabl \\
\hline 16 & Between groups & 11,27813714 & 6 & 1,879689524 & 1,070297168 & 0,403520281 & 2,445259395 \\
\hline 17 & Within groups & 49,17448 & 28 & 1,756231429 & & & \\
\hline 18 & & & & & & & \\
\hline 19 & Results & 60,45261714 & 34 & & & & \\
\hline 20 & & & & & & & \\
\hline
\end{tabular}

Fig 4. Single-factor dispersion yield analysis of winter wheat variety, - Kolchuga

\begin{tabular}{|c|c|c|c|c|c|c|c|}
\hline$\Delta$ & A & B & c & D & $\mathrm{E}$ & $\mathrm{F}$ & G \\
\hline 1 & \multicolumn{7}{|c|}{ Single-factor dispersion yield analysis (Zamozhnist variety) } \\
\hline 2 & & & & & & & \\
\hline 3 & RESULTS & & & & & & \\
\hline 4 & Groups & Score & Sum & Mean & Dispersion & & \\
\hline 5 & Control & 5 & 15,23 & 3,046 & 1,34938 & & \\
\hline 6 & $\mathrm{~N}_{30} \mathrm{P}_{30}$ (background) & 5 & 17,92 & 3,584 & 1,53808 & & \\
\hline 7 & Background + Urea K1 & 5 & 23,22 & 4,644 & 1,57553 & & \\
\hline 8 & Background + Urea K2 & 5 & 24,13 & 4,826 & 1,47103 & & \\
\hline 9 & Background + Escort-bio & 5 & 24,97 & 4,994 & 1,41388 & & \\
\hline 10 & $\begin{array}{l}\text { Background + Urea K1 + } \\
\text { Urea K2 }\end{array}$ & 5 & 24,74 & 4,948 & 1,44022 & & \\
\hline 11 & Background + Organic D2 & 5 & 24,82 & 4,964 & 1,45003 & & \\
\hline \multicolumn{8}{|l|}{12} \\
\hline \multicolumn{8}{|c|}{13} \\
\hline 14 & Dispersion analysis & & & & & & \\
\hline 15 & Source of variation & SS & $d f$ & MS & $F$ & P-Value & F tabl \\
\hline 16 & Between groups & 18,52678857 & 6 & 3,087798095 & 2,111180894 & 0,083653518 & 2,445259395 \\
\hline 17 & Within groups & 40,9526 & 28 & 1,462592857 & & & \\
\hline \multicolumn{8}{|l|}{18} \\
\hline 19 & Results & 59,47938857 & 34 & & & & \\
\hline
\end{tabular}

Figure 5. Single-factor dispersion yield analysis of winter wheat variety, - Zamozhnist

For identifying the dependence of yield on weather and climatic conditions during the growth and development of winter wheat, we use a linear dependence, because research of other scientists had proved that the dependence of grain yield in a certain period is linear [12].

It should be noted that in all interphase periods of the studied varieties of winter wheat, depending on the nutrition way, the connection became tight, and the most tight connection is characteristic for the interphase period "plant going into a tube - earing". It should be pointed that in this research weaker connection is characteristic for the period of "earing - full ripeness of grain".

The coefficient of determination $R^{2}$ for both varieties in the interphase period "plant going into tube - earing" varies in the range from 0.997 up to 0.999 depending on the way of nutritions, which indicates that the variation in winter wheat yield of 99.97-99.99\% is determined by the variation of weather and climatic conditions.

The coefficient of determination $R^{2}$ for the studied varieties for all ways of nutrition in the interphase period "spring tillering - plant going into 
tube" varies in the range from 0.949 to 0.985 , which indicates that the variation in winter wheat yield from $94.9 \%$ up to $98.5 \%$ is determined by the variation of weather and climatic conditions.

The coefficient of determination $R^{2}$ for varieties and ways of nutrition of the interphase period "earing - full ripeness of grain" varies in the range from 0.845 up to 0.914 , which indicates that the variation in the yield of winter wheat grain from 84.5 up to $91.4 \%$ is determined by changes in the temperature regime of the air and its humidity, as well as the amount of precipitation. It was found that Zamozhnist variety got weaker connection in specified interphase period.

To calculate the dependence of grain yield on agroclimatic factors and creating regression equations, based on the analysis of variance and close connection, we use data of the Zamozhnist variety with the option of nutrition Background + Escort-Bio during the period "plant going into tube - earing".

We identify the variables of the econometric model: let be $y$ - the yield of winter wheat, t/ha; $x_{1}-$ temperature, ${ }^{0} \mathrm{C} ; x_{2}$ - precipitation, $\mathrm{mm} ; x_{3}$-relative air humidity, $\%$.

A linear multi-factor econometric model of winter wheat yield has the form:

$$
\hat{y}=-12,779-0,049 x_{1}-0,054 x_{2}+0,283 x_{3}
$$

Regression coefficients show how many points in average the performance attribute $\mathrm{Y}$ will be changed when the factor attributes $x_{1}, x_{2}, x_{3}$ are changed for one mark. In other words, the coefficients show the average efficiency of independent factors and reflect the average increase in the result per unit factor.

In our case, a coefficient of -0.049 means that under the same conditions, with an increase in temperature by 1 , the yield will decrease on 0.049 $\mathrm{t} / \mathrm{ha}$, with not changed composition of other factors.

The coefficient -0.054 means that under the same conditions, with precipitation increase for 1 point, the yield will be decreased on $0.054 \mathrm{t} / \mathrm{ha}$, with not changed composition of other factors.

The coefficient 0.283 means that under the same conditions, with relative air humidity increase for 1 point, the yield will be increased on $0.283 \mathrm{t} / \mathrm{ha}$, with not changed composition of other factors.

The coefficient -12.779 indicates the projection of the regression line on the abscissa axis and the same time it is a mathematical start point of calculation. $\quad R=0,999-$ multiple correlation coefficient, which is a measure of the linear connection of a dependent variable $Y$ with independent variables $x_{1}, x_{2}, x_{3}$. Its value distinguishes a fairly strong relationship between the appropriate socio-economic indicators.

The value of the coefficient of determination for this model indicates that the variation in yield on 99.9\% is determined by the variation in temperature, precipitation and relative air humidity.

Partial elasticity coefficients:

$$
\begin{gathered}
E_{\frac{Y}{X_{1}}}=\frac{\frac{\partial \hat{Y}}{\partial X_{1}}}{\frac{\bar{Y}}{\bar{X}_{1}}}=\hat{a}_{1} \cdot \frac{\bar{X}_{1}}{\bar{Y}}=-0,275 ; \\
E_{\frac{Y}{X_{2}}}=\frac{\frac{\partial \hat{Y}}{\frac{\partial X_{2}}{\bar{Y}}}=\hat{a}_{2} \cdot \frac{\bar{X}_{2}}{\bar{Y}}=-0,487 ;}{\bar{X}_{2}} \\
E_{\frac{Y}{X_{3}}}=\frac{\frac{\partial X_{3}}{\bar{Y}}}{\frac{\bar{X}_{3}}{\bar{X}_{3}}}=\hat{a}_{3} \cdot \frac{\bar{X}_{3}}{\bar{Y}}=6,186 .
\end{gathered}
$$

The calculated partial elasticity coefficients show that increase of air temperature for $1 \%$ will go with further decrease in yield on 0.275 , as long as other factors stayed constant. If precipitation increase for $1 \%$, the yield will decrease on 0.487 , as long as other factors stayed constant. Increase of relative air humidity for $1 \%$ will show an increase in the yield of winter wheat grain on 6,186 , as long as other factors stayed constant.

Total elasticity is: $A=\sum_{j=1}^{n} E_{\frac{Y}{X_{j}}}=5,425$. Total elasticity shows that when all counted factors increase simultaneously for $1 \%$, the yield will increase on 5,425 .

The statistical significance of estimates of model parameters was checked according to the $t-$ Student's statistics at the significance level $\alpha=0,05$ . The model parameters were found statistically significant, which means they have a significant impact on the independent variable $Y$.

We will use the Fischer criterion to test the adequacy of the econometric model to actual data, the hypothesis about the significance of the connection between independent and dependent variables.

Consider a hypothesis $H_{0}: R^{2}=0$ versus an alternative hypothesis $H_{A}: R^{2}>0$. This is equivalent to checking the significance of all model parameters at the same time (hypothesis $H_{0}: \hat{a}_{0}=\hat{a}_{1}=\hat{a}_{2}=\hat{a}_{3}=0 \quad$ vs. $\quad$ alternative hypothesis $\left.H_{A}: \hat{a}_{0} \neq 0, \hat{a}_{1} \neq 0, \hat{a}_{2} \neq 0, \hat{a}_{3} \neq 0\right)$. Let is determine actual value of $F-$ Criterion ( $\left.F_{\text {qakm }}=321,768\right)$ and compare it with the table 
value. The table value for a given significance level $\alpha=0,05$ and the number of degrees of freedom is $k_{1}=2$ and $k_{2}=2: F_{\text {табл }}=F_{0,05 ; 2 ; 13}=19$. Since $F_{\text {факт }}>F_{\text {табл }}$, the null hypothesis is rejected and the econometric model can be considered adequate to the actual data with a given probability $\mathrm{p}=0.95$, which means that hypothesis about the significance of the connection between independent and dependent variables is confirmed.

Let is check the accuracy of the econometric model using the average relative approximation error, we have

$$
\bar{\varepsilon}=\frac{1}{n} \sum_{i=1}^{n}\left|\frac{y_{i}-\hat{y}_{i}}{y_{i}}\right| \cdot 100 \%=1,22<10 \%
$$

this indicates the high quality of the model. Provided research job gives us the conclusion that the influence of weather and climatic conditions in different interphase periods of growth and development of winter wheat plants is quite significant.

Conclusions. The yield of winter wheat grain is highly depends and changes under the influence of weather conditions of vegetation stage, biological characteristics of the variety and the supply of plants with nutrients. Despite of cultivation year, significantly higher grain yield and lower variability of winter wheat is provided by the cultivation of the Zamozhnist variety, with applying of mineral fertilizers background in moderate dose and foliar feeding with Escort-Bio crops as $4.99 \mathrm{t} / \mathrm{ha}$.

Correlation and regression analysis showed close connection between yield and temperature, precipitation, and relative air humidity. Multivariate regression is created with the significance of $A=0,5$. It was shown that under the same conditions, with an increase of temperature for 1 point, the yield of winter wheat will decrease on $0.049 \mathrm{t} / \mathrm{ha}$, with not changed composition of other factors; with an increase of precipitation for 1 point, the yield will decrease on $0.054 \mathrm{t} / \mathrm{ha}$, with not changed composition of other factors, and with an increase in relative air humidity for 1 point, the yield will increase on $0.283 \mathrm{t} / \mathrm{ha}$, with not changed composition of other factors.

\section{Список використаних джерел:}

1. Barabash M. B., Korzh T. V. \& Tatarchuk O. H. (2004) Doslidzhennia zmin ta kolyvan opadiv na rubezhi KhKh i KhKhl st. v umovakh poteplinnia hlobalnoho klimatu. Naukovi pratsi UkrNDHMI. 253. 92-102.

2. Blyshchyk D. V., Polovyi A. M. \& Feoktistov P. O. (2014) Blok dynamichnoi modeli formuvannia zymostiikosti roslynamy ozymoi pshenytsi na pivdni Ukrainy v zalezhnosti vid strokiv sivby. Problemы materyalnoi kulturb. Heohrafycheskye nauky. 273. 83-88.

3. Vozhehova R. A. (2012) Adaptatsiia zemlerobstva stepovoi zony do umov pidvyshchennia posushlyvosti klimatu. URL : http://unt.org.ua/adaptats-ya-zemlerobstva-stepovo-zoni-do-umov-p-dvishchennya-posushlivost-kl-matu

4. Vozhehova R. A. (2019) Napriamy adaptatsii haluzi roslynnytstva do rehionalnykh zmin klimatu. Klimatychni zminy ta silske hospodarstvo. Vyklyky dlia ahrarnoi nauky ta osvity. Tezy II Mizhnar. nauk.-prakt. konf., 10-12 kvitnia 2019 r. Kyiv - Mykolaiv Kherson: DU NMTs «Ahroosvita», 6-8.

5. Hrytsiuk P. M. (2015) Modeliuvannia vplyvu meteofaktoriv na vrozhainist ozymoi pshenytsi. Haluzeva, mizhhaluzeva ta rehionalna ekonomika. Vcheni zapysky. 12. 216-224.

6. Hrytsiuk P. M. (2009) Prohnozuvannia vrozhainosti zernovykh kultur: osoblyvosti i metodyka. Vcheni zapysky [Kyivskyi natsionalnyi ekonomichnyi universytet im. Vadyma Hetmana]. 11. 294-300.

7. Hrytsiuk P. M. \& Bachyshyna L. D. (2016) Vplyv zminy klimatychnykh umov na dynamiku vrozhainosti zernovykh v Ukraini. Ekonomika Ukrainy. 6 (655). 68-75.

8. Hrytsiuk P. M. \& Bachyshyna L. D. (2015) Modeliuvannia vplyvu meteofaktoriv na urozhainist zernovykh kultur v rozrizi oblastei Ukrainy. Visnyk Khmelnytskoho natsionalnoho universytetu. Ekonomichni nauky. 1 (3). 184-188.

9. Dmytrenko V. L. (2003) Adaptatsii melioratyvnoho zemlerobstva do pohody i klimatu. Visnyk ahrarnoi nauky. 2. 52-56.

10. Kazakova I. (2016) Vplyv hlobalnykh zmin na gruntovi resursy ta silskohospodarske vyrobnytstvo. Agricultural and Resource Economics. 2 (1). 21-44.

11. Kobets S. P. \& Tesolkin O. I. (2018) Pidkhid do prohnozuvannia vrozhainosti ozymoi pshenytsi z urakhuvanniam vplyvu osnovnykh hidrometeorolohichnykh faktoriv. Hlobalni ta natsionalni problemy ekonomiky. 23. 701-705.

12. Kobets S. P. \& Tesolkin O. I. (2018) Pidkhid do prohnozuvannia vrozhainosti ozymoi pshenytsi z urakhuvanniam vplyvu osnovnykh hidrometeorolohichnykh faktoriv. Hlobalni ta natsionalni problemy ekonomiky. 23. 701-705.

13. Kucherenko O. M., Khomenko L. O., Kovalyshyna H. M. \& Kochmarskyi V. S. (2013) Vplyv zminy klimatu na osoblyvosti morfolohichnoho analizu pry otsintsi stanu perezymivli pshenytsi m'yakoi ozymoi. Selektsiia i nasinnytstvo. 103. 107-114. DOI: 10.30835/2413-7510.2013.54075

14. Liashenko V. V. \& Marenych M. M. (2010) Vplyv strokiv sivby na produktyvnist posiviv pshenytsi ozymoi. Visnyk Poltavskoi derzhavnoi ahrarnoi akademii. 2. 46-50.

15. Marenych M. M. (2019) Urozhainist zerna pshenytsi v umovakh zminy klimatu. Klimatychni zminy ta silske hospodarstvo. Vyklyky dlia ahrarnoi nauky ta osvity. Tezy II Mizhnar. nauk.-prakt. konf., 10-12 kvitnia 2019 r. Kyiv : Mykolayiv: Kherson : DU NMTs «Ahroosvita», 26-28.

16. Prokopenko A. (2013) Yakshcho vzymku ne bude ekstremalnykh pohodnykh umov, to tsohorichnyi vrozhai zbizhzhia perevershyt torishnii. Zerno i khlib. 1. 6-8. 
17. Rudych O. O. (2018) Pryrodno-klimatychni umovy yak faktor ryzyku vyrobnytstva silskohospodarskoi produktsii v Ukraini. Stalyi rozvytok ekonomiky. 2 (39). C. 14-21.

18. Rudnyk-Ivashchenko O. I. (2012) Osoblyvosti vyroshchuvannia ozymykh kultur za umov zmin klimatu. Sortovyvchennia ta okhorona prav na sorty roslyn. 2. 8-10.

19. Symonenko O. I. (2016) Dynamichni ekonometrychni modeli prohnozuvannia vrozhainosti ozymoi pshenytsi na osnovi otsiniuvannia pryrodno-klimatychnykh kharakterystyk. Naukovyi visnyk Natsionalnoho universytetu bioresursiv $i$ pryrodokorystuvannia Ukrainy. Seriia: Ekonomika, ahrarnyi menedzhment, biznes. 249. 363-372. URL : http://nbuv.gov.ua/UJRN/nvnau_econ_2016_249_43.

20. Tarariko O. H., llienko T. V. \& Kuchma T. L. (2016) Vplyv zmin klimatu na produktyvnist ta valovi zbory zernovykh kultur: analiz ta prohnoz. Ukrainskyi heohrafichnyi zhurnal. 1. 14-22. DOI: 10.15407/ugz2016.01.014.

21. Tarariko O. H., Syrotenko O. V., Ilienko T. V. \& Velychko V. A. (2012) Kosmichnyi monitorynh posushlyvykh yavyshch. Visnyk ahrarnoi nauky. 10. 16-20.

22. Tarariko Yu. O., Chernokozynskyi A. V. \& Saidak R. V. (2008) Vplyv ahrotekhnichnykh i ahrometeorolohichnykh faktoriv na produktyvnist ahroekosystem. Visnyk ahrarnoi nauky. 5. 64-67.

23. Udova L. O., Prokopenko K. O. \& Didkovska L. I. (2014) Vplyv zminy klimatu na rozvytok ahrarnoho vyrobnytstva. Ekonomika $i$ prohnozuvannia. 3. 107-119.

24. Gitay H., Suarez A., Watson R. T. \& Dokken D. J. (eds). (2002) Climate Change and Biodiversity. IPCC Technical Paper V. Intergovernmental Panel on Climate Change. URL: https://archive.ipcc.ch/pdf/technical-papers/climate-changes-biodiversityen.pdf.

25. Hunt L.A. \& Pararajasingham S. (1995) CROPSIM-wheat: a model describing the growth and development of wheat. Canadian journal of plant science. 75 (3). 619-632.

26. Leonardis E.D., Savitch L.V., Huner N.P.A., Oquist G. \& Grodzinski B. (2003) Daily photosynthetic and C-export patterns in winter wheat leaves during cold stress and acclimation. Physiolia Plantarum. 117. 521-531.

27. Martin P. N., Gent \& Ido Seginer (2012) A carbohydrate supply and demand model of vegetative growth: response to temperature and light. Plant, Cell and Environment. 35. 1274-1286.

28. McMaster G. S. (1993) Existing wheat yield models. Distributed listing. Fort Collins : USDA - ARS Crops Research Lab, CO.

29. Porter John R. \& Semenov Mikhail A. (2005) Crop responses to climatic variation. Philos Trans R Soc Lond B Biol Sci. Nov 29; 360 (1463). 2021-2035. DOI: 10.1098/rstb.2005.1752.

30. Ritchie J. T., Godwin D. C. \& Otter-Nacke S. (1985) CERES Wheat. A simulation Model of Wheat growth and Development college Station. Texas: Texas. AM University Press.

\section{А. М. Могильницкая, А. В. Панфилова. Оценка и моделирование влияния погодно-климатических условий на урожайность пшеницы озимой}

Рассмотрены агроклиматические условия выращивания сортов озимой пшенищы на юге Украины при различных вариантах питания. Для каждой фазы развития культуры проанализировано изменения температуры воздуха, количества осадков, относительной влажности и их совместного влияния на ее производительность в современный климатический период (2011-2016 г2.). Найдено основные выборочные характеристики результатов взаимодействия сортов пшенищы и построена многофакторная регрессия зависимости урожайности от гидрометеорологических факторов.

Ключевые слова: урожайность, агроклиматические условия; озимая пшеница регрессия; корреляция.

\section{А. М. Могильницька, А. В. Панфілова. Оцінка та моделювання впливу погодно- кліматичних умов на урожайність пшениці озимої}

Розглянуто агрокліматичні умови вирощування сортів пшенищі озимої на півдні України при різних варіантах живлення. Для кожної фази розвитку культури проаналізовано зміну температури повітря, кількості опадів, відносної вологості та їх сумісного впливу на їі продуктивність у сучасний кліматичний період (2011-2016 рр.). Знайдено основні вибіркові характеристики результатів взаємодії сортів пшениці та побудовано багатофакторну регресію залежності урожайності від гідрометеорологічних чинників.

Ключові слова: урожайність, агрокліматичні умови; пшениця озима; регресія; кореляція. 